\title{
Çizgi Film Çevirisinde Onomastik Etki
}

\author{
Yrd. Doç. Dr. SEVTAP GÜNAY KÖPRÜLÜ*
}

\section{Öz}

Çocuklar, günün büyük bir kısmını televizyon karşısında çizgi film izleyerek geçirmektedir. İzledikleri arasında yerli çizgi filmlerin yanı sıra Türkçeye çevrilmiş birçok yabancı çizgi filmler de yer almaktadır. Çocukların gördükleri olayları, sevdikleri kişileri genellikle taklit ettikleri göz önüne alındığında, dil ve davranış yönünden izlediklerinden etkilendiklerini söylemek mümkündür. Bu nedenle çizgi film çevirisi üzerinde durulması gereken ve bu alanda daha çok bilimsel çalışma yapılması gereken bir konudur.

$\mathrm{Bu}$ çalışmada çizgi filmlerde geçen kişi ve yer adlarının hedef dile çevirileri ele alınmıştır. Bu amaçla, yakın zamanda televizyon ve sinemalarda yayınlanan yabancı çizgi filmlerde geçen özel adlar, hedef dile çevirileri, hangi adların çevrildiği veya çevrilmediği, özel ad çevirisinde uygulanan çeviri yöntemleri incelenmiş ve örneklendirilmiştir. Araştırma sonucunda, çizgi filmlerde geçen özel adların çevirisinde belirli bir kıstasın olmadığı, kimi adların yerelleştirildiği, kimilerinin taşıdığı anlama veya çağrışımına göre uyarlanarak çevrildiği, kimi adların ise olduğu gibi bırakıldığı veya atlandığı görülmüştür.

Anahtar sözcükler: Çizgi film, onomastik, özel ad, çeviri, çocuklar

\section{THE ONOMASTIC EFFECT ON CARTOON TRANSLATION}

\section{Abstract}

The children spend most of the day by watching cartoons on television. In addition to the native cartoons they watch, there are also many foreign cartoons translated into Turkish. Children often imitate the events they see and the people they love. Hence, it is possible to say that they are influenced by what they see in terms of language and behavior. For this reason, cartoon translation is a topic that needs to be emphasized and scientifically studied more.

In this paper, the translation of the names of characters and places in cartoons into the target language is discussed. For this purpose, the proper nouns used in foreign cartoons that have recently been broadcasted on television and cinema, the matter of how they are translated into the target language and the translation methods used for this purpose are scrutinized and exemplified. This research states that there is no specific criterion in the translation of proper nouns in cartoons, some names are localized, some are

\footnotetext{
* Nevşehir Hacı Bektaş Veli Üniversitesi Eğitim Fakültesi Almanca Öğretmenliği, sgkoprülü@hotmail.com
} 
adapted/translated depending on the meaning and connotation they have, and some are left as they are and lastly, some are ignored.

Keywords: Cartoons, onomastic, proper noun, translation, children

\section{Giriş}

حizgi filmler günümüzde çocukların en çok izlemeyi tercih ettikleri yayın türleridir. Ülkemizde son zamanlarda yerli yapım çizgi filmlerin sayısı artmış

5 olsa da henüz yeterli sayıda değildir. Bu nedenle sinemaların yanı sıra televizyonlarda Türkçeye çevrilmiş birçok yabancı yapım çizgi filmler yer almaktadır. Kimi çizgi filmlerde kültürel özellikler, folklorik temalar ön plandadır (Prenses Kaguya Masalı'nda olduğu gibi). Çocuklar genel olarak tüm yabancı çizgi filmlerde, özellikle de folklorik temalı filmlerde yabancı oldukları konularla, farklı yer ve kişi adlarıyla, giyim-kuşam, yeme alışkanlıkları gibi kültürel değerlerle karşılaşırlar.

Çocukların vakitlerinin çoğunu televizyon karşısında çizgi film izleyerek geçirdiği ve gördükleri davranışları, sevdikleri kişileri genellikle taklit ettikleri göz önüne alındığında, dil ve davranış yönünden etkilenmediklerini söylemek mümkün değildir. Bu nedenle 'çizgi film çevirisi' üzerinde durulması gereken ve bu alanda daha çok bilimsel çalışma yapılması gereken bir konudur. Ne var ki ülkemizde bu alanda yeterli çalışmaya rastlanmamaktadır.

$\mathrm{Bu}$ çalışmada özel adlar ve çevirilerine ilişkin kuramsal bilgilere yer verildikten sonra çizgi filmlerde geçen kişi/karakter ve yer adlarının hedef dile çevirileri incelenmiş ve çeviribilimsel çerçevede değerlendirilmiştir. Bu kapsamda güncel olarak televizyon ve sinemalarda yayınlanan çizgi filmlerde geçen özel adlar ve bu adların hedef dile nasıl aktarıldıkları incelenmiştir.

\section{1. Çizgi Film ${ }^{1}$}

Cambridge Advanced Learner's Dictionary \& Thesaurus² sözlügüne göre çizgi film, "genelde eğlenceli, gerçekten daha ziyade çizilmiş karakterler ve resimler kullanılarak yapılan bir televizyon programı veya kısa filmdir".

Çizgi film sinema terimi anlamında, "bir konuyla ilgili olarak karakterlerinin hareketlerini belirtecek biçimde art arda çizilmiş resimlerden oluşan sinema filmi" (Türk Dil Kurumu Güncel Türkçe Sözlük) olarak tanımlanmaktadır.

Televizyon kanallarındaki çizgi filmler genellikle, yaklaşık 15-20 dakika süren ve her bölümde farklı bir temanın işlendiği ancak temelde birbirine bağlı seri bölümler şeklinde

\footnotetext{
${ }^{1}$ Çalışmada çizgi film ve animasyon ayrımı gözetilmemiştir.

${ }^{2} \mathrm{http} / / /$ dictionary.cambridge.org/dictionary/english/cartoon (erişim, 16.11.2016)

${ }^{3}$ www.tdk.gov.tr (erişim, 10.11.2016) 
gösterilmektedir; diğer bir deyişle bir nevi pembe dizidirler. Sinemada gösterilen çizgi filmler ise, tek gösterimliktir ve daha uzun sürer. Ancak son yıllarda sinema çizgi filmlerinde de seri gösterimler başlamıştır: Arabalar 1-2, Kung Fu Panda 1-2-3, Madagaskar 1-2-3, Buz Devri $1-2-3-4$.

Çizgi filmlerde karakterlere verilen adlar genellikle rastgele olmamaktadır. Karakterlerin adları onların kişilik özelliklerini (Pamuk Prenses gibi), fiziksel özelliklerini (Keloğlan gibi), etnik kökenini (Kaguya, Heidi gibi) vb. yansitmaktadır. Çocuk aynı zamanda kendi kültürel ortamından farklı giyim kuşam ve çevre

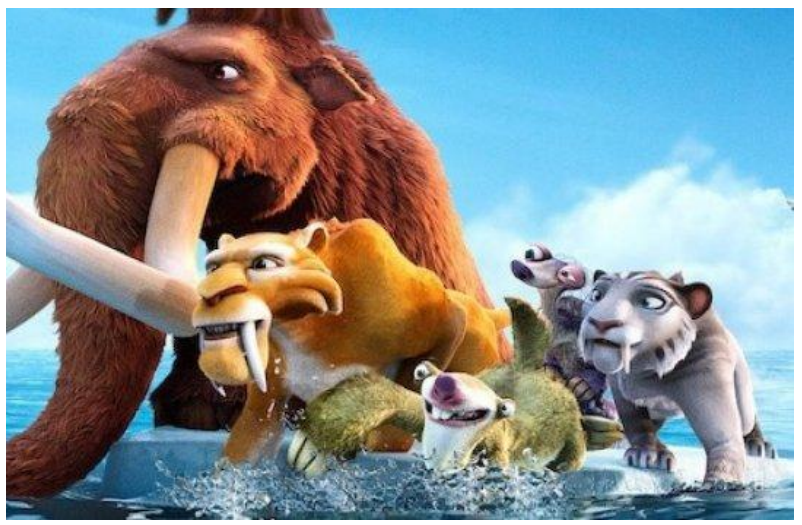
içerisinde alışık olmadığı bir adı (örneğin Winx çizgi filminde teknolojinin koruyucu perisi olan 'Tecna' adını) duyduğunda ise yabancı bir çevreye/kültüre ait olduğunu algılayabilir.

Yabancı yapım çizgi filmlerde özellikle adlar ve hitaplar ilk önce dikkat çeken kültürel farklılıklardır. Küçük kardeş büyügüne 'abi', 'abla' yerine adıyla seslenir; 'kerata', 'koçum' gibi ifadeler yer almaz. Danslar, yemekler, çocuk oyunları, müzikler farklıdır. Peki, bu kadar farklılık içinde özel adlar çevrilmeli midir ya da yerelleştirilmesi ne kadar doğrudur?

\section{Onomastik}

Yunanca kökenli bir kavram olan Onomastik (Alm. Namenkunde, İng. Onomastics) geniş anlamda, "anlambilimle yakınlığı olan, ancak yöntem bakımından ondan ayrılan ve sözcükkavram ilişkisine önem veren bilim dalı"dır. Dar anlamda ise, "genellikle her dilde özel ad sayılan ögeler üzerinde duran ve özel adları kökenbilgisi, tarihsel gelişme yönünden ve çeşitli dil ve kültür sorunları açısından inceleyen bilimdir." (Aksan 1995: 32, 415-421).

Onomastik' in inceleme alanına giren özel ad bugüne değin genel olarak "tek bir kişiyi, belli bir canlı ya da cansız varlı̆̆ı, bir düşünce ya da belli bir yeri anlatan adlar" olarak tanımlanmıştır (416).

Özel ad denilince akla ilk gelenler, kişi adları, şehir adları, ülke adları, kurum adlarıdır. Bunların dışında dil, din, ulus, kitap, dergi, gazete, dernek adları gibi geniş bir yelpazeye sahiptir. Kül Kedisi, Pamuk Prenses gibi masal karakterleri, Winx, Spiderman gibi fantastik kurgu karakterleri, gemi, uçak veya tren adları, olaylar ve koşullar vb. özel ad kapsamindadır.

Adların ses biçimleri, tarih içerisinde toplumdan topluma büyük ölçüde değişmiştir. Örneğin, Yahya (Tr.), Hans (Alm.), John (İng.) aynı kökene dayanmaktadır. Alexander (Alm.), Alexandre (Fr.) ile İskender (Tr.) aynı kişi adıdır. Euphrates bugün bizde Fırat olarak 
kullanılmaktadır. Bütün bu değişmelerin ana nedeni, bu türden özel adların yüzyıllar boyunca değişik ülkelerde farklı dillerde söylenmiş olmasıdır (Aksan 1995: 417).

Zengin'in (2006: 35-36) de belirttiği gibi, kişi adları incelenirken, toplumdaki ad verme gelenek ve göreneklerinin iyi bilinmesi gerekir. Bir kişiye ad verilmesine ilişkin yasal düzenlemeler, Alman toplumuyla Türk toplumunda farklıdır. Ad olarak verilmesi uygun olduğu sürece Türk toplumunda "Çicek", "Ramazan", "Aslan”, “Bulut” gibi tür adları kişi adı olarak verilebilir. Çocuğun anne ve babası tarafından uydurulan, bilinçli bir biçimde yapılan (örneğin, anne Feriha, baba Hüseyin, çocuğun adı Feryin) adlar da vardır. Ayrıca başta Arapça ve Farsça adlar olmak üzere, diğer yabancı dillerden birçok ad alınmıştır. Ancak çocuğa konulan adların resmiyet kazanabilmesi için uyulması gereken yasal ilkeler söz konusudur. ${ }^{4}$ Alman toplumunda ise, bir kişiye ad verme, adın kişiyi rencide etmemesi, küçük düşürmemesi ve ad olarak verilmeye uygun bir sözcük olması anlamında bizimkiyle benzerlik gösterse de tür adlarının kişi adı olarak verilmesine izin verilmemesi nedeniyle farklılık gösterir ${ }^{5}$. Örneğin kız çocuğuna “Blume” (Çiçek) ya da erkek çocuğuna "Löwe" (Arslan) tür adları kişi adı olarak verilemez. Bu nedenle Alman kişi adları, eski Germen adlarından ve Latince, Yunanca, Fransızca gibi birçok yabancı dilden alınan adlardan oluşur. Örneğin Peter, Petrus adının bir varyasyonudur. Latince (Petrus) veya Yunanca (Pétros) kökenlidir; Pétros anlamı kaya, taş demektir ${ }^{6}$ (Duden Sözlük). Tür adı bir kişiye veya bir yere verildiği zaman artık özel ad olur. Tür adı büyük yazılmazken özel ada dönüşmüş tür adları büyük yazılır. Almancada ise, sadece özel adlar değil, bütün adlar büyük yazılır. Ancak İngilizcede sadece özel adlar büyük yazılır.

\section{3. Çeviribilimsel Kapsamda Özel Adların Çevirisi}

Chiaro'nun (2009: 155) da bahsettiği gibi, görsel-işitsel çevirilerde, özellikle dilsel ve kültürel zorluklar ön plana çıkmaktadır. Bu zorluklar arasında kişi ve yer adları, para birimleri, kurumlar gibi kültür odaklı gönderimler de yer almaktadır.

Genel kanı özel adların çevrilmeden hedef dile aktarılması gerektiği yönündedir. Ancak uygulamada özel adların işlevlerine göre çevrilebilir olduğu, hatta çevrilmesi gerektiği görülmektedir. Örneğin, Michael Ende'nin Die unendliche Geschichte (Bitmeyecek Öykü) adlı eserini İngilizceye çeviren Ralph Manheim, eserde geçen özel adları sadece

\footnotetext{
41587 sayılı Nüfus Kanunu'nun 16. maddesinde "çocuğun adını ana ve babası kor. Ancak ahlak kurallarına uygun düşmeyen veya kamuoyunu inciten adlar konulmaz" ibaresi yer almaktaydı. Bu kanun 5490 sayılı Nüfus Hizmetleri Kanunu'yla yürürlükten kaldırılmıştır. Dolayısıyla bu ibare artık yer almamaktadır. Yine Nüfus Hizmetlerine Ait Kuruluş Görev ve Çalışma Yönetmeliği'nin 77. maddesinde “çocuğun adını ana ve babası koyar, ancak, milli kültürümüze, ahlak kurallarına, örf ve adetlerimize uygun düşmeyen veya yasaya aykırı ya da kamuoyunu inciten adlar konulamaz" ibaresi yer almaktayken bu yönetmelik de kaldırılmıştır.

${ }_{5}$ Almanya'da kişi ön adlarının verilişine dair bir kanun yoktur. Ancak buna ilişkin mahkeme kararları gibi düzenleyici uygulamalar vardır.

${ }^{6}$ www.duden.de/rechtschreibung/Peter_Person_schwarzer_Peter (erişim, 10.11.2016)
} 
çevirmekle kalmamış aynı zamanda fonetik olarak hedef dilde çağrışım yaptığı ada göre uyarlamıştır (Fuchur $\rightarrow$ Falkor, Phantásien $\rightarrow$ Fantastica). Yine Harry Potter filminin Hollanda diline çevirisinde iki en iyi arkadaş olan Ronald Bilius Weasley $\rightarrow$ Ronald Virus Wemel ve Hermione Granger $\rightarrow$ Hermelien Griffel olarak adlandırılmıştır. Almanca' da ise Hermione $\rightarrow$ Hermine olmuştur.

Ülkemizde ise son zamanlarda çocuklara yönelik çizgi filmlerde özellikle de erken çocukluk dönemine yönelik çizgi filmlerde geçen yabancı adların yerine Türkçe adlar verildiği görülmektedir. Örneğin Damlanın Dolabı (Chloe's Closet), Chloe $\rightarrow$ Damla, Lovely Carrot $\rightarrow$ Havuç Kafa, Tara $\rightarrow$ Tuğba, Jet $\rightarrow$ Berk, iiley $\rightarrow$ Reha,

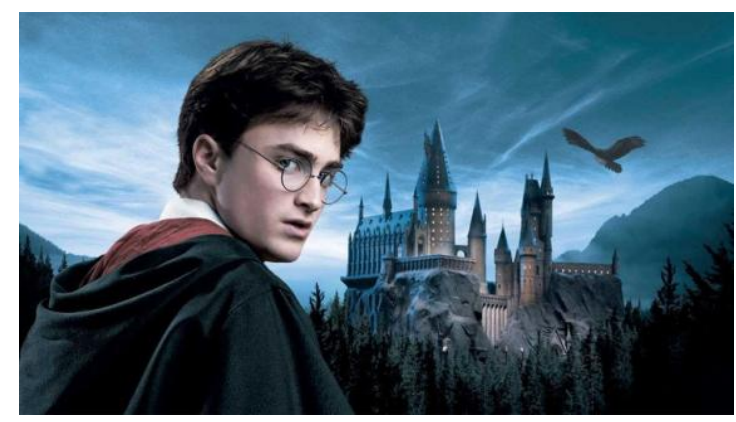
Danny $\rightarrow$ Didem. Bu örneğimizde, kaynak dildeki özel adların yerelleştirme yöntemiyle hedef dile çevrildiğini, bunu yaparken de fonetik benzerlik gösteren kişi adlarının tercih edildiğini görüyoruz. Çeviribilimde "yabancılaştırma" ve "yerelleştirme" çeviri yöntemlerinin temeli Schleiermacher'e dayanmaktadır (bkz. Venuti, 1995: 4, 19-20). Schleiermacher'in "yabancılaştırıcı çeviri" (verfremdende Übersetzung) ve "yerelleştirici çeviri" (einbürgernde Übersetzung) teorisinden hareket edecek olursak çizgi filmlerde geçen özel adların hiç değiştirilmeden hedef dile aktarılması "yabancılaştırıcı çeviri", hedef dilde kullanılan uygun karşılıklarının bulunması ise "yerelleştirici çeviri” özelliği taşımaktadır.

Hayri Canavargil (Henry Hugglemonster) adlı çizgi filmde ise biraz daha farklı bir yerelleştirme söz konusudur. Henry $\rightarrow$ Hayri, Summer $\rightarrow$ İlkyaz, Cobby $\rightarrow$ Bilgin, Ivor $\rightarrow$ Tek Diş, Daddo $\rightarrow$ Babişko, Momma $\rightarrow$ Annişko, Beckett $\rightarrow$ Bıdık, Denzel $\rightarrow$ Minişko. Burada, 'Henry' adı, hedef dilde fonetik açıdan benzerlik gösterdiği 'Hayri' kişi adıyla yerelleştirilirken diğer adlar uyarlanmıştır. Summer $\rightarrow$ İlkyaz olarak çevrilmiştir. Zira 'Summer' yaz demektir. Türkçe ad verme geleneğinde ilk olan çocukların adının başına 'ilk' sözcüğü eklenir (örneğin İlker, İlknur). Bu nedenle Canavargil ailesinin ilk ve tek kız çocuğu Summer, İlkyaz şeklinde uyarlanarak Türk ad verme geleneğine de yakınlaştırılmış ve içeriksel, anlamsal ve biçimsel eşdeğer bir çeviri sağlanmıştır. Biçimsel olarak da eşdeğerdir zira tür adı (Summer) yine tür adı (İlkyaz) olarak adlaştırılmıştır. Fantastik, gerçek hayatta olması mümkün olmayan figürlerin söz konusu olduğu çizgi filmlerde tür adları karakter adı olarak kullanılmaktadır. Bu nedenle hedef dile anlamına göre çeviri yapılması hedef kitle açısından yerinde bir uygulamadır. Diğer yandan Hayri'nin abisi Cobby'nin Türkçede 'Bilgin' olmasının nedeni karakter özelliğine göre uyarlanmış olmasıdır. Bebek Ivor ise, görülen tek dişinden dolayı 'Tek Diş' olarak uyarlanmıştır. 
Diğer yandan ise, My Little Pony adlı çizgi filmde, ne filmin adı ne de karakterlerin adı (örneğin Rainbow Dash, Pinkie Pie, Fluttershy, Twilight Sparkle, Rarity, Applejack) değiştirilmiştir. Filmde geçen İngilizce adlar, yer adları da dahil (örneğin Ponyville) olduğu gibi hiçbir şekilde değiştirilmeden Türkçeye aktarılmıştır. Böylelikle "yabancılaştırma" yapılmıştır. Yabancılaştırma, metnin yabancı özelliklerini öne çıkaran ve hedef kültürü arka plana atan bir çeviri stratejisidir (Venuti, 1995: 20). Bunun yanı sıra, kaynak dilde geçen ve belirli bir amaca göre verilmiş, bir anlam taşıyan karakter adlarının hedef dile olduğu gibi aktarılması nedeniyle hedef dil alıcısı tarafından kolaylıkla anlaşılamamaktadır. Dolayısıyla çeviride "iletişimsel eşdeğerlik" gözetilmemiştir. Wilss'in (1977) çeviri yaklaşımına göre, çeviri sürecinde çevirmen, kaynak metnin içeriğini ve biçemini anlayarak çözümledikten sonra metnin iletişimdeki etkisini de gözeterek eşdeğer bir şekilde hedef dile aktarmalıdır. Bunun yanı sıra, Koller (1997), çevirinin, kaynak metnin işlevini yerine getirebilmesi için çeviri sürecinde yorumlama ve değiştirme yapılabileceğini ileri sürmektedir.

Aynı şekilde, İsviçreli yazara ait romandan uyarlanmış olan Heidi adlı çizgi filmde de, özel adların değiştirilmeden Türkçeye aktarıldığını görüyoruz: Heidi $\rightarrow$ Heidi, Base Dete $\rightarrow$ Dete Teyze, Peter $\rightarrow$ Peter, Alm-Öhi $\rightarrow$ Alm-Öhi, Tobias $\rightarrow$ Tobias, Adelheit $\rightarrow$ Adelheit, Frankfurt $\rightarrow$ Frankfurt. Bu çizgi filminin çevirisinde özel adlar aynen aktarılmış olsa da aynı açıdan değerlendirilmemelidir. Şöyle ki, örneğin My Little Pony çizgi filmi tamamen kurgusal, gerçek hayatla bağlantısı olmayan ütopik bir çizgi film iken Heidi gerçek hayata çok yakın olan ve gerçek hayattan izler taşıyan (Frankfurt, Mainfield, Heidi, Peter gibi) bir filmdir. Bu nedenle bu özel adların olduğu gibi hedef dile aktarılması gerekmektedir.

Zengin (2006: 39), özel adların bir alt grubunu oluşturan yer adlarının çevrilemez olduğunu, şayet herhangi bir yer adı, hem kaynak ve hem de hedef dilde varsa, o zaman hedef dildeki şeklinin alınabileceğini belirtir. Örneğin bir ülke adı olan Österreich (Alm.) $\rightarrow$ Avusturya. Heidi'de geçen şehir adı Frankfurt çeviride aynı kalmıştır, zira hedef dil içinde bu şehir için kullanılan farklı bir ad bulunmamaktadır.

Diğer yandan Şimşek McQueen adlı çizgi filmde Carburetor Country $\rightarrow$ Karbüratör Bölgesi olarak çevrilmiştir. Zira böyle bir kasaba kurgusaldır, filmin içeriğine göre uydurulmuş bir kasaba adıdır ve hedef dile çevrilmesi gereklidir. Almanca çevirisinde ise bu bölge adı hiç geçmemektedir7. Ancak My Little Pony çizgi filminde aynı mantıkla hareket edilmediğini görüyoruz. Örneğin midillilerin yaşadığı yerin adı Ponyville aynen alınmıştır.

Özel adların çevirisine dair çeviribilimsel çevrede bugüne kadar hem fiki olma durumu söz konusu olmamıştır. Bir metin içerisinde, diğer bir deyişle bir bağlam içinde geçen özel adların çevirisine yönelik bilimsel dayanağı olan belirli bir yöntem zikredilmemektedir. $\mathrm{Bu}$ nedenle de bunların çevirisi çevirmenin (veya işverenin) şahsi

\footnotetext{
${ }^{7}$ www.youtube.com/watch?v=7hDbwfhchUc (erişim 20.11.2016)
} 
kararına ve onun yaratıcılığına bırakılmış durumdadır. Nitekim Lutz Rühling (1992: 154), natüralist romanlarda geçen coğrafik adların çevirisine ilişkin yaptığı araştırmasında bazı adların çevrildiğini, bazılarının çevrilmediğini, bazı çevirmenlerin sadece bir kategoride yer alan coğrafik adları çevirdiklerini, diğerini ise çevirmediklerini belirterek Hermans (1988) ve Gläser'in (1976), özel ad çevirilerinin henüz bir standardının olmadığına yönelik tespitlerine işaret etmektedir.

Özel adların çevirisine ilişkin Schreiber (1993: 180-181), modern yazınsal çevirilerde kişi adlarının kuralda aynen alındığını, ancak çocuk kitapları çevirilerinde büyük ölçüde şahıs adlarının yerelleştirildiğini; diğer çeviri türlerinde ise, örneğin uzmanlık alan çevirilerinde veya belge çevirilerinde yer ve kişi adlarının yerelleştirilmesinin prensipte kabul edilemez olduğunu belirtir.

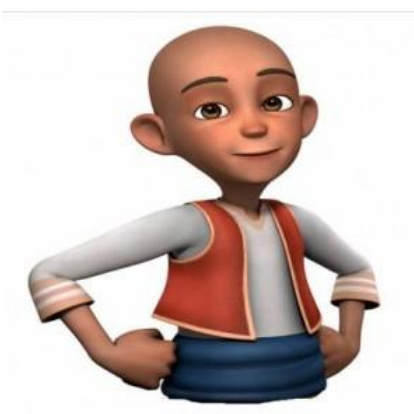

Prensipte bir anlamı, bir tasvir işlevi, karakteristik özellik belirtme işlevi olmadığı sürece özel adlar çevrilemez. Yazınsal eserlerde veya çocuklara yönelik eserlerde özel adlar özellikle de karakter adları sadece figürleri adlandırmakla kalmaz tasvir edici nitelik kazanır (örneğin Keloğlan, Demir Adam, Pamuk Prenses). Bu durumda hedef dile çevrilebilirler, hatta çevrilmelidirler. Nitekim özel adların çeviri sorunlarına ilişkin araştırmaları olan Kalverkämper (2000) de, kaynak dilde geçen, anlamı olan ve bir şeye çağrışım yapan bir özel adın anlamının hedef dile çevrilmesi taraftarıdır.

Diğer yandan, Zengin (2006: 37), anlamları anlaşılan adların (Aslan) hedef dile çevrilmesi (Alm. Löwe, İng. Lion) durumunda, 'Aslan' adının Türkçede öncelikle adı taşıyan bireyi çağrıştırırken 'Löwe' adının bir Almana öncelikle yırtıcı hayvanı çağrıştıracağını ve dolayısıyla önceliklerin yer değiştireceğini belirterek kişi adlarının çeviride olduğu gibi alınması gerektiğini belirtir. Bununla ilgili olarak Heidi örneğini verebiliriz: Heidi'nin annesinin adı olan Adelheid/Adelheit, Adal (= edel, asil, soylu anlamindadır) ve heit (aslında bir sonektir, ancak eski yüksek Almancada varlık anlamındadır) sözcüklerinin birleşiminden oluşmuş eski bir addır. Dolayısıyla "asil varlık" 8 anlamındadır. Bu ad da anlamına göre çevrilmemiş olduğu gibi alınmıştır. Çevrilmesi de zaten uygun olmazdı. Zira 'Adelheit' adı Heidi'nin annesinin göstergesidir ve taşıdığı anlamdan sıyrılmıştır. Bunun yanı sıra böylesine gerçek hayatı yansıtan ve filmde geçen birçok yerin ve kişi adlarının (olayların değil) gerçekle örtüştüğünü göz önüne alırsak salt Adelheit adının Asilvarlık olarak Türkçeye aktarılması kabul edilemez olurdu.

Özel adın çevrilmesi hâlinde ad hedef dilde aynı çağrışımı yapıyorsa, aynı göstergeye işaret ediyorsa, aynı imge oluşuyorsa ve eşdeğer işleve sahipse kaynak dildeki özel adın

\footnotetext{
${ }^{8}$ Bkz. http://wiki-de.genealogy.net/Adelheid_(Vorname)
} 
taşıdığ1 anlam hedef dile çevrilmelidir. Bu durum özellikle gerçek hayatla bağlantısı olmayan ütopik çizgi filmlerde karakterlerin fiziksel veya karakteristik özelliklerine yönelik ad verilmesi durumunda söz konusu olur. Ancak özel ad çevrildiğinde hedef alıcıda farklı bir gösterge/imge oluşmasına neden oluyorsa ve hedef dilde karşıllı̆̆1 yoksa çevrilmeden bırakılmalı, aynen alınmalıdır. Bu durum gerçek hayattan izler taşıyan gerçekçi çizgi filmlerde geçen özel adlar için geçerlidir.

Heidi çizgi filminde, Heidi'nin Alplerde yaşayan dedesi 'Alm-Öhi' olarak anılmaktadır9. Alm, Alp dağının uzantısı bir dağın adıdır. Öhi ise, Almanca Oheim (amca) adının kısaltmasıdır. Dolayısıyla Alm dağında yaşayan dedenin adı (bir nevi lakabı) öyküntü çeviri (İng. calc) yöntemiyle "Alm-Amca” olarak verilebilirdi. Nitekim Heidi'nin animasyon filminde Alm-Öhi $\rightarrow$ amca olarak geçmektedir. ${ }^{10}$ Ülkemizde öyküntü çeviri aracilığıyla tanınmış olan karakterler vardır: Spiderman $\rightarrow$ Örümcek Adam, Ironman $\rightarrow$ Demir Adam.

Diğer yandan, yine Heidi örneğinden devam edecek olursak filmin orijinalinde geçen Barbel adı, Türkçesinde geçmemektedir ${ }^{11}$. Oysa filmin Almancasında ilk bölümlerinde Dete teyze, Heidi'yi dedesine bırakmaya giderken ve dönüşte Barbel ile konuşmakta ve köylü kadın arkadaşı Barbel'in adını sık sık kullanmaktadır. ${ }^{12}$

Bunların dışında, kaynak ve hedef dilde aynı kullanılan bir ad var ise (örneğin Alm. Maria, Tr. Meryem) o zaman hedef dildeki karşılığının kullanılabileceği akla gelebilir. Ancak bu durum, sıklıkla yabancı adın yer aldığı bir eserde izleyicide tepkiye neden olabilir, izleyici o karakterin kendi kültüründen olduğu izlenimine kapılabilir. Bu nedenle diğer özel adlar çevrilmeden bırakılmış ise, her ne kadar eşdeğeri hedef dilde olsa dahi (Maria $\rightarrow$ Meryem) hedef dildeki karşılığıyla verilmemesi daha doğru bir karar olacaktır. Bu durum özellikle hedef kitlesi küçük yaş grubu olan çeviriler için daha geçerlidir. Ancak örneğin tarihte bilinen Büyük İskender'i konu alan veya Meryem Ana'yı konu alan bir filmin çevirisi söz konusu ise, bu adların hedef dildeki eşdeğer karşılıklarının kullanılması gerekir. Zira burada her iki dilde adlar aynı kişiye işaret etmektedir.

Çizgi filmlerde geçen özel adların çevirisinde dikkati çeken diğer bir husus ise sözcük oyunlarının olduğu adlardır: Hayri Canavargil'de babanın adı 'Dad' sözcüğünü çağrıştıran Daddo, annenin adı 'Mom' sözcüğünü çağrıştıran Momma'dır. Tür adından sözcük oyunuyla özel ad yapılmıştır. Türkçe çevirilerinde kaynak dilin sözcük oluşturma stilini yansıtacak şekilde 'Babişko' ve 'Annişko' adları kullanılmıştır. Kaynak sözcüğün stiline uygun eşdeğer bir çeviri yapılmıştır. Bu anlamda Koller (1997: 216), biçimsel-estetik

\footnotetext{
${ }^{9}$ www.youtube.com/watch?v=6NXVpqfK3AI (erişim, 16.11.2016)

${ }^{10}$ www.youtube.com/watch?v=B71-1m3eujU (erişim, 20.11.2016)

11 www.youtube.com/watch?v=6NXVpqfK3AI ve www.youtube.com/watch?v=Vw_0NZPkwJ8 (erişim, 16.11.2016)

${ }^{12}$ Animasyon filminin Türkçesinde ise Barbel adı geçmektedir.bkz. www.youtube.com/watch?v=B71-1m3eujU (erişim, 16.11.2016)
} 
eşdeğerlikten (Alm. formal-ästhetische Äquivalenz) bahseder. Bu, kaynak metnin belirli estetik, biçimsel ve bireysel tarz özelliklerini koruyan eşdeğerlik türüdür.

Diğer yandan, Şimşek McQueen filminde spiker Bob Cutlass'ın, Türkçesinde aynı kalırken Almancasında 'Heiko Water' olarak çevrildiği görülmüştür. Bob Cutlass filmde bir spor spikeridir ve gerçek hayatta Amerikan televizyonlarında spor muhabirliği yapan Robert Quinlan “Bob" Costas'1 fonetik açıdan

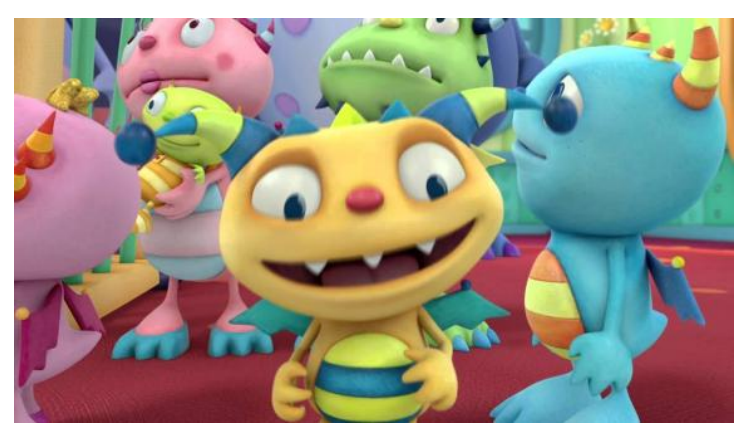
çağrıştırmaktadır. Almanca çeviride geçen Heiko Water adı ise, Almanya'da Formula 1 yarışları spikeri ve spor yazarı olan Heiko Waßer adını çağrıştırmaktadır. Bu tür ad çevirisi tercihi çeviribilim kapsamında değerlendirdiğimizde, adların değiştirilerek kaynak dildeki adların uyarlanarak yerine hedef dilde aynı işlevi gören bir ad kullanılması ve soyadlar üzerinde yapılan değiştirmelerle biçimsel ve işlevsel eşdeğerliğin (Koller, 1997) dikkate alındığını görüyoruz. Aynı zamanda bu tarz çeviri için "yerine geçme" (substitution) kullanıldığını da söyleyebiliriz. Dilbilimsel açıdan bu yöntem “bir sözcede yer alan öğelerden birinin yerine bir başka öğe koyma" (Vardar, 2002: 151) olarak tanımlanmaktadır. Bir dil ögesinin, ona denk olan, aynı anlamı veren başka bir ögesiyle değiştirilmesidir. Aynı şekilde Şimşek McQueen filminde yine bir gerçek kişi adından uyarlama yapıldığını görüyoruz: Darrel Cartrip, spor spikeri Darrell Waltrip'in adının uyarlanmasıyla oluşturulmuş bir addır. Almanca çevirisinde Chris Dinner adı ise, eski bir Alman yarış pilotu ve Formula 1 spikeri olan Christian Danner adından uyarlamadır. Ancak bu iki ismin Türkçe çevirisinde uyarlama yapılmamış, "yerine koyma" yöntemi uygulanmamış olduğu gibi aktarılmıştır.

\section{Sonuç ve Öneriler}

Bu çalışmada, günümüz çizgi filmlerinde geçen özel adların hedef dile nasıl aktarıldı̆̆ı, hangi çeviri yöntemlerinin kullanıldığı tespit edilmeye çalışılmıştır. Hedef dilde özel adlar karşılık buluyor mu, hangi çeviri yöntemiyle nasıl çevriliyor soruları araştırılmıştır. Yapılan araştırma sonucunda görülmüştür ki çizgi filmlerin hedef dile çevirisinde gözetilen belirli bir ölçüt yoktur. Kimi çizgi filmde özel adlar hedef dilde yerelleştirilirken veya içerdiği anlama göre uyarlanırken kimilerinde hiç değiştirilmeden olduğu gibi alınmış ve böylece yabancılaştırılmıştır. Bu şekilde yabancılaştırmanın nedeni, çocuklara kendi dünyalarından, çevresinden ve kültüründen çok daha farklı fantastik ve yabancı bir dünyanın olduğu ortamda adların da yabancı kalmasının uygun olduğunun düşünülmüş olması olabilir belki 
ancak, izledikleri filmde geçen özel adların daha anlaşılır olması çocuklar için bir avantajdır. Diğer yandan filmde çok fazla tekrarlanmayan adlar ise çeviride atlanmıştır.

Özel adların en önemli görevi, farklı nesneleri, kişileri ve yerleri tanımlamak, onlara bir kimlik kazandırmaktır. Bu nedenle özellikle karaktere yönelik ipuçları veren özel adların hedef dile çevrilmesi, çocukların karakteri daha kolay çözmesine ve daha kolay hatırlamasına yardımcı olur. Bunun yanı sıra Damla'nın Dolabı çizgi filminde olduğu gibi, filmde kültürel vurgulama yoksa özel adların belirgin bir işlevi yoksa ve çağrışımsal yapıda değilse adların yerelleştirilmesi, olması gereken bir yaklaşımdır.

Çocuklar için çeviri yaparken, kaynak filmde bulunan yabancı adlara, yaptığı çağrışımlara, göstergesine, anlamına hedef dilde eşdeğeri olup olmadığına dikkat edilerek çocuklar için en doğru karar olacak bir politikanın benimsenmesi gerekmektedir. Çocuklara yönelik eserlerin çevirisinde, kullanılan dil, buna özel adlar da dâhil, çocukların yadırgamayacağı bir biçimde olmalıdır. Gerçek hayattan alınan kişi adları çevrilemez belki, ancak çocuklara yönelik kurgusal karakterlerin kurgusal adları çevrilebilir, hatta çevrilmelidir. Bu kişi adının ait olduğu milletinin bilinmesi önemli değilse, diğer bir deyişle filmde kültürel unsurlar ön planda değilse, karakter veya yer adının bir anlamı varsa, bir şey çağrıştırıyorsa hedef dile uyarlanarak çevrilmelidir. Çevirisi yapılmadan bırakılan adların anlamını çocuk bilemez. Ayrıca, çocuklar için kendi dillerindeki eşdeğerlerini hatırlamak ve tekrarlamak çok daha kolay olur.

\section{Kaynakça}

Aksan, Doğan (1995). Her Yönüyle Dil. Ankara: Türk Dil Kurumu Yayınları.

Chiaro, Delia (2009). "Issues in Audiovisual Translation", içinde The Routledge Companion to Translation Studies, (Ed. Jeremy Munday), (Revised edition). Oxon: Routledge, pp. 141163.

Gläser, Rosemarie (1976). "Zur Übersetzbarkeit von Eigennamen", içinde Linguistische Arbeitsberichte (Leipzig), 13, S. 12-25.

Hermans, Theo (1988). “On Translation Proper Names, with reference to ‘De Witte' and 'Max Havelaar'", içinde Modern Dutch Studies. Essays in honour of Peter King (Ed. Michael Wintle). London: The Athlone Press, S. 11-24.

Kalverkämper, Hartwig (2000). “Kontaktonomastik - Namen als Brücken in der Begegnung von Menschen und Kulturen", içinde Onomastik. Bd. 2 Namensysteme im interkulturellen Vergleich (Ed. Dieter Kremer). Tübingen: Niemeyer, S. 6-20.

Koller, Werner (1997): Einführung in die Übersetzungswissenschaft. (5. Auflage). Heidelberg; Wiesbaden: Quelle \& Meyer. 
Rühling, Lutz (1992). “Fremde Landschaft. Zum Problem der geographischen Eigennamen in den Übersetzungen von Strindbergs naturalistischen Romanen", içinde Die literarische Übersetzung als Medium der Fremderfahrung (Ed. Fred Lönker). Berlin: Göttinger Beiträge zur Internationalen Übersetzungsforschung Bd. 6, S. 144-172.

Schleiermacher, Friedrich (1973). "Methoden des Übersetzens (1813)”, içinde Das Problem des Übersetzens (Ed. Hans Joachim Störig). Darmstadt: Wissenschaftliche Buchgesellschaft, S. 38-70.

Schreiber, Michael (1993): Übersetzung und Bearbeitung. Zur Differenzierung und Abgrenzung des Übersetzungsbegriffs. Tübingen: Gunter Narr Verlag

Vardar, Berke (2002). Açıklamalı Dilbilim Terimleri Sözlüğü. İstanbul: Multilingual.

Venuti, Lawrence (1995). The Translator's Invisibility: A History of Translation (2nd ed.). Londra: Routledge.

Wilss, Wolfram (1977). Übersetzungswissenschaft. Probleme und Methoden. Stuttgart: Ernst Klett. Zengin, Dursun (2006). Almancaya Çevrilen Türk Masallarında Çeviri Sorunları. Ankara: Türk Dil Kurumu Yayınları: 873.

www.duden.de (erişim, 10.11.2016)

http://dictionary.cambridge.org/dictionary/english/cartoon (erişim, 16.11.2016).

www.tdk.gov.tr (erişim, 10.11.2016)

www.youtube.com (10.11.2016) 